
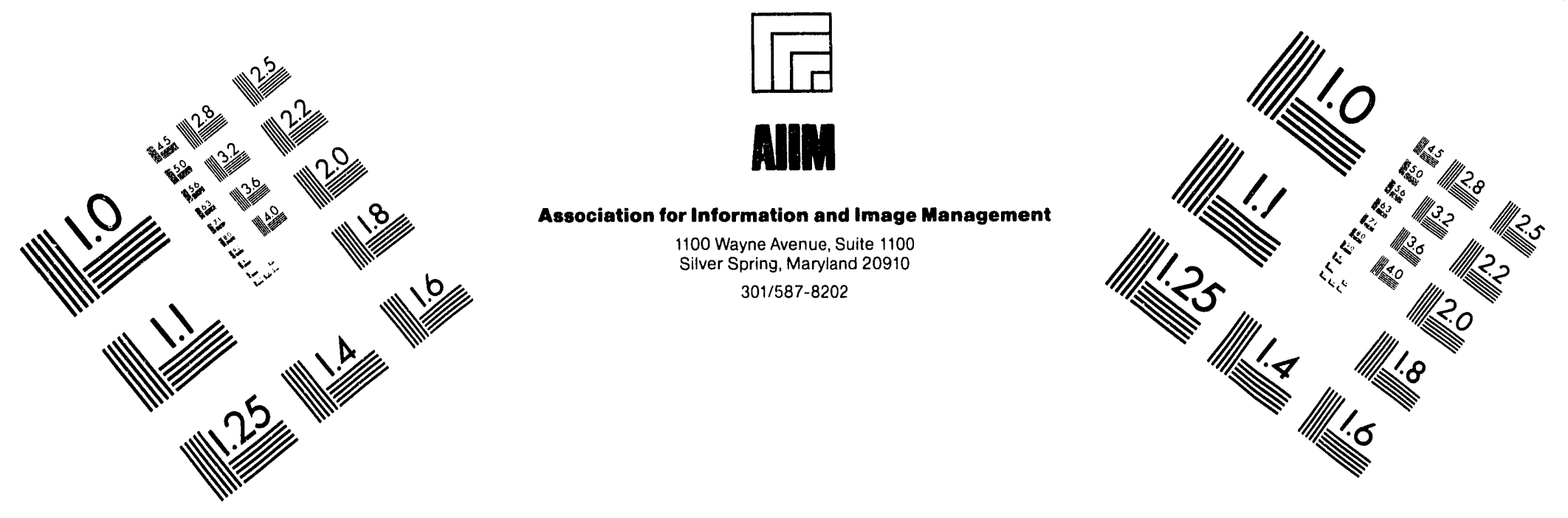

\title{
Centimeter
}

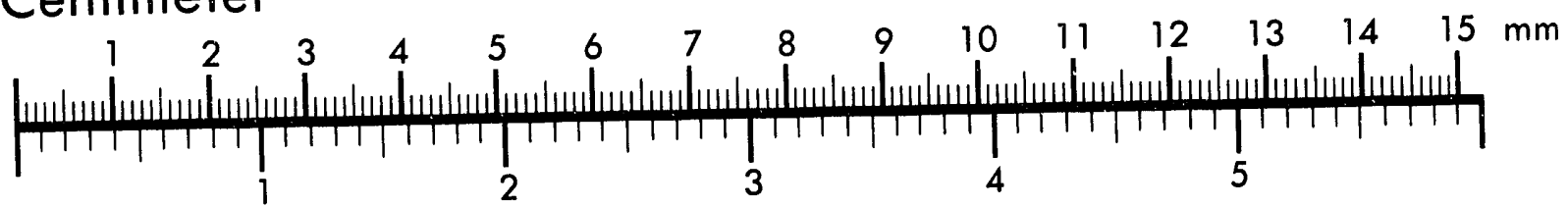
Inches
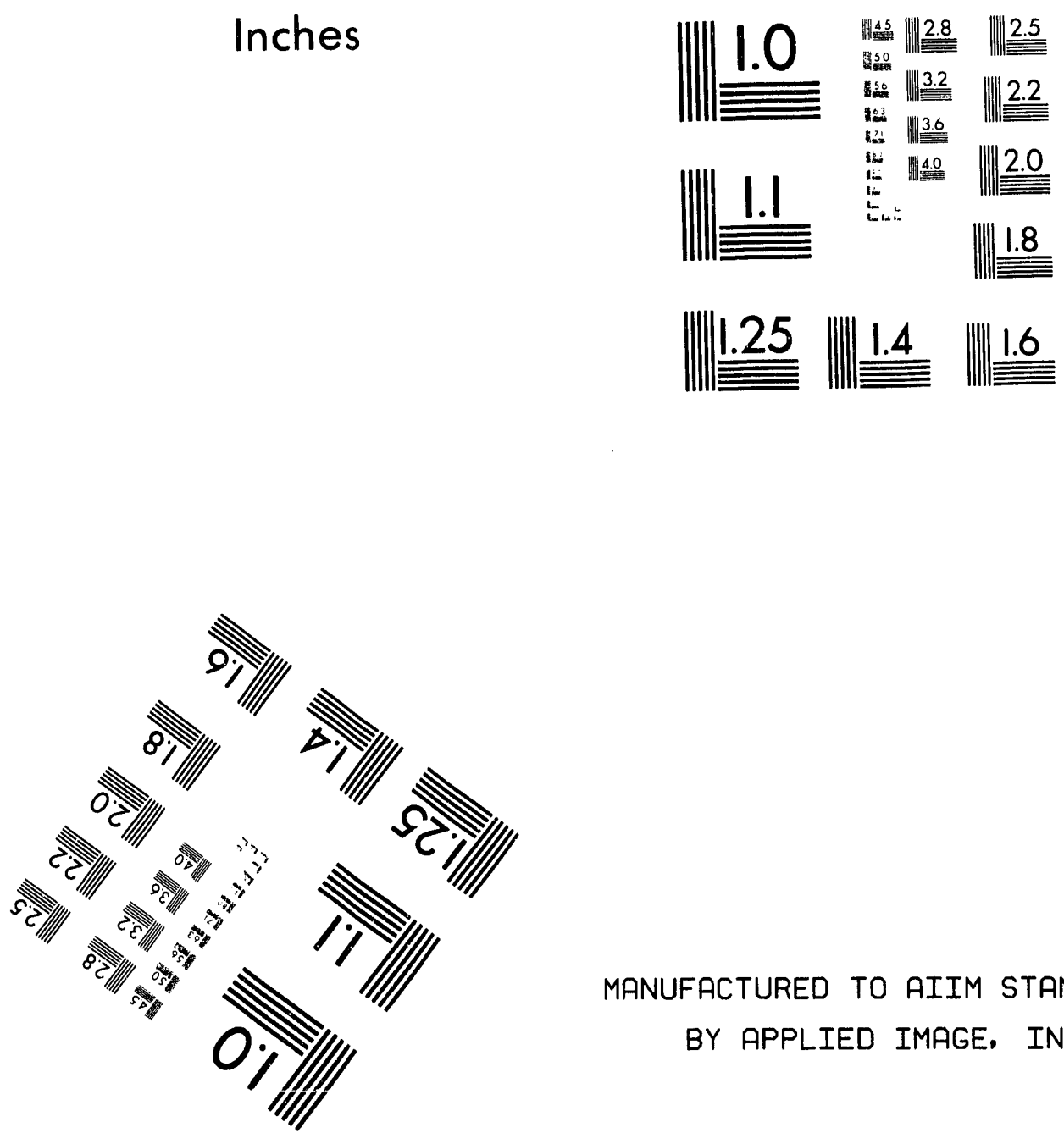

MANUFACTURED TO AIIM STANDARDS

BY APPLIED IMAGE, INC.

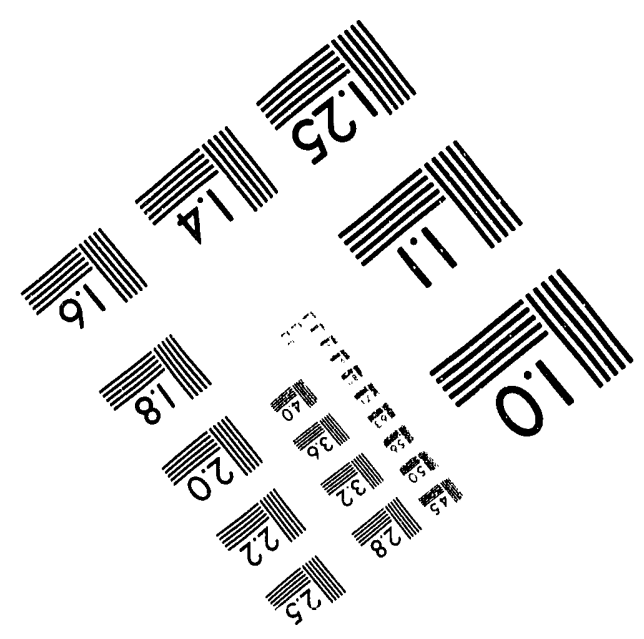



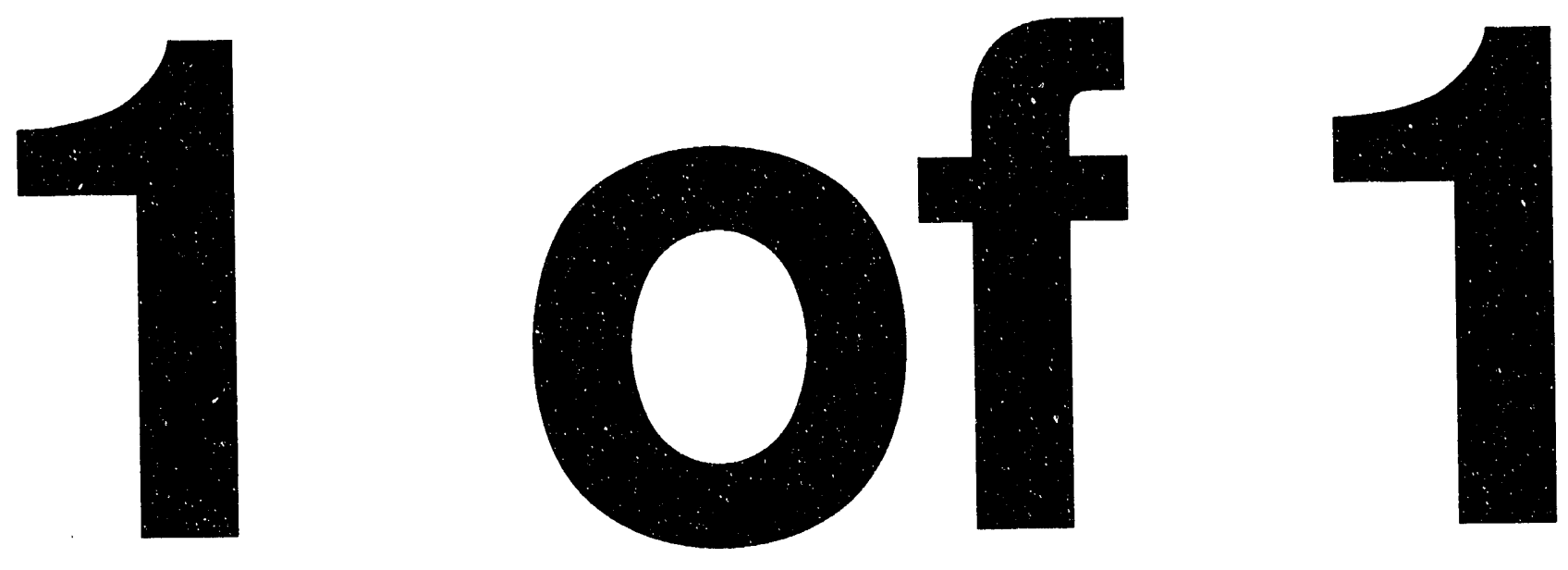
D. B. Moore-Shedrow, Section Manager

Authorized Derivative Classifier

March 15, 1993

Projected Tritium Releases from F \& H Area Seepage Basins and the Solid Waste Disposal Facilities to Fourmile Branch (U)

Authors/Contributors:

B. B. Looney

J. S. Haselow

C. M. Lewis

M. K. Harris

D. E. Wyatt

C. S. Hetrick

Authenticated by:

B. B. Looney B. Loony

Environmental Sciences Section

Savannah River Technology Section

Approved by:

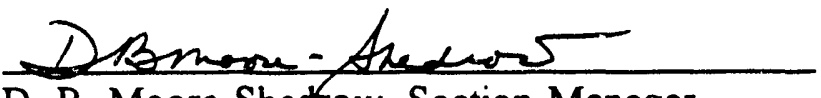

D. B. Moore-Shedrow, Section Manager

Environmental Sciences Section

Savannah River Technology Section

Prepared for the U. S. Department of Energy under Contract No. DE-AC09-89SR18035. 


\section{Projected Tritium Releases from F \& H Area Seepage Basins and the Solid Waste Disposal Facilities to Fourmile Branch}

\section{Introduction and Summary}

A large percentage of the radioactivity released to the environment by operations at the Savannah River Site (SRS) is due to tritium, a radioactive isotope of hydrogen. Tritium is generated as a product or byproduct of specific-identified SRS processes. Over the years, tritium has accumulated in various wastes/products, or has entered the environment through atmospheric or liquid releases. The releases have been carefully measured and documented. All of the data on tritium in the vicinity of SRS are provided to the public in widely distributed annual environmental reports. In 1990, for example, tritium was the greatest contributor $(94.4 \%)$ to the total dose for users of downstream Savannah River public water supplies. Importantly, the maximum 1990 dose commitment for all radionuclides at BeaufortJasper SC and Port Wentworth GA was $0.075 \mathrm{mrem}$, only $1.8 \%$ of the EPA standard for drinking water (4 mrem/year). Despite the low concentrations, the U. S. Department of Energy (DOE) has a commitment to take additional actions, as appropriate, to reduce public exposure resulting from SRS releases. The entire release of tritium in 1990 to the Savannah River was about $16000 \mathrm{Ci} ; 84 \%$ of this total was from groundwater flow to Fourmile Branch in the vicinity of the $\mathrm{F}$ and $\mathrm{H}$ Area Seepage Basins and the nearby Solid Waste Disposal Facilities (SWDF). Because of the relative importance of the releases from these facilities through the groundwater to the environment, periodic evaluation and documentation of the facility operational status, proposed corrective actions, and projected changes/reductions in tritium releases are justified.

Past, current, and projected tritium releases from the F and $\mathrm{H}$ Area Seepage Basins and the SWDF to Fourmile Branch are described below. In each section, a brief operational history is provided, along with the current status and proposed corrective actions. Based on the background information, a conceptual model and quantitative estimates of tritium release, or flux, from the facilities into the groundwater and the environment are developed. In general, tritium releases from the $F$ and $H$ Area Seepage Basins, facilities that were closed in 1988, are declining. These releases will be further reduced by the implementation of a groundwater corrective action required by the Resource Conservation and Recovery Act (RCRA). Tritium releases from the SWDF have been relatively stable over the past 10 years. Based on the operational history of the facility, and the geology and hydrology of the site, we anticipate that, with no corrective action, SWDF tritium releases to Fourmile Branch will remain approximately at current levels for at least $10-20$ years. Specific characterization activities, including three dimensional (3D) characterization of the tritium plume in the groundwater downgradient of the SWDF and further source term characterization, are recommended. The additional characterization information will allow a significantly improved projection of tritium flux and assist in developing plans for plume mitigation. Similar to the $F$ and $H$ Area Basins, SRS and the South Carolina Department of Health and Environmental Control (DHEC) are currently developing groundwater corrective action plans for the SWDF. Portions of the SWDF is are also regulated under the Comprehensive Environmental Response, Compensation, and Liability Act (CERCLA); CERCLA characterization and assessment are also underway. Reduction of tritium flux is one of the factors considered in 
the development of the RCRA/CERCLA groundwater corrective action. Low permeability caps, wasteform stabilization, groundwater barriers, groundwater pump-treat-reinjection, and other technologies are all under consideration as relevant components of the SWDF remediation.

The final section of the document presents the sum of the projected tritium fluxes from these facilities to Fourmile Branch. The projections are most reliable the next few years. No credit was taken for corrective action at the SWDF since the nature and impact of the remediation is currently not defined. Thus, we anticipate that the estimates are conservative (high) beyond approximately year 2000 .

\section{Overview of the Geology and Hydrology of the Facilities}

As shown on Figure 1, the F and H Area Seepage Basins and the SWDF are located in the center of SRS between two streams -- Upper Three Runs to the north and Fourmile Branch to the south. Recharge to the groundwater in this area is primarily due to infiltration of rainwater (rainfall minus runoff and evapotranspiration). Groundwater moves downward and laterally, draining to the nearby streams. As expected, there is a groundwater divide in the shallow water bearing zones. North of the divide, flow is toward Upper Three Runs and its tributaries and south of the divide, flow is toward Fourmile Branch and its tributaries. In the vicinity of the basins and the southern portion of the SWDF, the shallow groundwater discharges to Fourmile Branch.

Measurements (e.g., flow and contaminant concentrations) in surface waters and in groundwater downgradient of these facilities have been performed from the 1950s through the present. Additionally, examination of cores from drilling and boring and geological descriptions of the area have been performed during this period. Most of the flow to Fourmile branch occurs in the upper two water-bearing layers -- a water table zone and a semiconfined zone. A leaky aquitard (clayey zone) is present between these zones. Within these zones, there are areas with higher and lower permeability. This structure controls the water flow rates, the contaminant plume shape, and the contaminant arrival times and locations in the downgradient surface water. Figure 2, which is a recent map of the tritium plume in the vicinity of the basins and SWDF, shows that the tritium flux to Fourmile Branch in this area results from the seepage basins and flow exiting the southwest comer of the SWDF. As expected, vertical water flow in these plumes follows a curved path downward near the source and then upward into the draining surface water (Figure 3 ). The surface water monitoring stations in the vicinity of these facilities are shown in Figure 4 . These stations have been used to determine the groundwater flux of tritium to Fourmile Branch and to associate the fluxes in the various stream reaches to the upgradient facilities. These historical data are an accurate measure of past tritium releases from these facilities to Fourmile Branch, and they are used as the basis of our projections in the following sections. 


\section{F and $H$ Area Seepage Basins}

\section{Operational History and Conceptual Model}

The $\mathrm{F}$ and $\mathrm{H}$ Area Seepage Basins received large volumes of dilute aqueous wastes from the late 1950s through 1988. The primary dissolved constituents in the wastewater were hydrogen ions (low $\mathrm{pH}$ ), nitrate, and sodium. The wastewater also contained relatively low concentrations of other chemical constituents (e.g., mercury, cadmium, and lead). The radioactive constituent with the highest activity in the wastewater was tritium; other relatively mobile radionuclides in the wastewater included ${ }^{90}$ Strontium, ${ }^{99}$ Technetium, and ${ }^{129}$ Iodine. A large amount of operational data, geology studies, groundwater and plume chemistry data, ecology characterizations, hydrology studies and modeling studies are available to support decision-making for these facilities. Observations in the sediments, groundwater, wetlands, and streams underlying and downgradient of the F and $H$ Area Seepage Basins are indicative of the behavior of contaminants under the substantively perturbed conditions during basin operations (see Fenimore and Horton 1968 \& 1972; Christensen and Gordon 1983; Killian et al. 1987a \& 1987b; Looney et al. 1988; Haselow et al. 1990; Corbo et al. 1985; Dixon and Rogers 1992):

- $\quad$ During basin operations, relatively large volumes of water were added to the subsurface, maximizing the driving force to move contaminants through the underlying sediments into the groundwater and to the downgradient hydrologic boundary (primarily Fourmile Branch).

- Breakthrough of tritium and nitrate was measured in the downgradient wetlands in the early 1960's.

- The shapes of the groundwater plumes indicate that there are permeable sediments and/or large scale heterogeneities in the downgradient system that result in relatively rapid flow.

- $\quad$ The bulk chemistry in the contaminant plume has been altered (increases ionic strength, reduced $\mathrm{pH}$, etc.). This tends to reduce the partitioning of metal ions to the soil because of competition with hydrogen ion for exchange sites; Also, the perturbation in bulk chemistry results in a more aggressive solution chemistry and enhances the leaching of constituents from the sediments in the flow path. The chemical shift would also tend to generate and stabilize colloidal solids that are a documented transport vector for small amounts of a normally sorbed contaminant.

- Sediment cores from the basins indicated that a large fraction of the contaminants normally assumed to have relatively high distribution coefficients are held up in the sediments above the water table, despite the bulk chemistry of the plume. 
- Following basin closure, tritium fluxes to the seep line have begun to decline as these contaminants flush from the system.

In the baseline case, water enters the system from infiltration (and formerly the basins) and exits to the wetlands along Fourmile Branch. With pump-treat-reinjection, a fraction of the water that would exit along the seep is reinjected upgradient. Thus, over time, there will be losses around the edge of the system equal to the infiltration. In the early years, the flow of water to the wetland is substantially reduced. As the system reaches steady state, infiltration of water continues and water flow to the stream will return to its former rate (shifted to the sides of the remediation area). Even at steady state, however, the wells can be placed so that a significant fraction of the tritium will remain in the recirculating water, allowing time for radioactive decay. This is the conceptual basis for the initial corrective action for the groundwater contaminated during operation of the F and H Area Seepage Basins.

\section{Transfer Function Modeling}

To facilitate quantitative projection of tritium fluxes and to provide initial estimates of the impacts of corrective action implementation, a straightforward analytical model of contaminant transport from the seepage basins to the downgradient stream was developed. The model was formulated to allow simple evaluation of the effectiveness of remediation scenarios. The approach used in the model is an intuitive "transfer function" similar to that developed by Jury (1982) for describing transport of agricultural contaminants. The transfer function model assumes that the flow system, in this case the flow path between the basins and the seep line, may be entirely described using a mathematical equation to transform the contaminant input record into a contaminant output prediction. The mathemarical transformation used is selected based on its consistency with measured data and the assumed governing chemical and physical processes. Such models typically simplify the complex processes governing transport into a function that has only a few parameters. Specific flow and dispersion relationships and permeability variations caused by channels or barriers are not explicitly described. Instead, the transfer function model estimates the average and extreme behavior of the contaminant based on the field measured distribution of travel times. Such models are good predictive tools if: (1) sufficient historical data on input and output flux are available, (2) historical input and output can be simply related, and (3) perturbations to the system are describable and relatively small. High quality measurements of tritium input to the $F$ and $H$ Area seepage basins every year of operation are available; similar measurements of tritium flux to Fourmile Branch beginning in 1958 (H Area) and 1967 (F Area) are also available. As discussed below, a log normal transit time assumption appears reasonable for both areas -- providing a simple mathematical function. Applying the model to relatively simple scenarios as a screening tool provides results that are useful to project fluxes into the future. Updated numerical modeling of these areas, calibrated using all of the historical flux, plume shape, geology, and water level data is being completed in parallel to provide documentation of final corrective action decisions. The numerical model will be used to refine tritium flux projections and to extend the analysis (e.g., potential future remediation systems incorporating barriers). 
In the transfer function model for the $F$ and $H$ Area Basins, each year's tritium flux to the basins is allowed to reach the seep line as described by a probability density function. The flux contribution from a particular year $(t)$ to the seepline in a future year $(t+d t)$ is equal to the original input flux times the value of the transfer function for a time shift of dt. The total area under the probability density function is 1.0 (for nondecaying contaminants) so that all of the contaminant input to the system in any year leaves the system over time. By superposition, the predicted contaminant output history is simply the sum of all of the various years' contributions. For radioactive constituents, the radioactive decay constant is incorporated into the transfer function to account for contaminant loss during the transit. A large number of investigators have examined subsurface hydraulic conductivity and flow variations (Jury et al. 1982 \& 1987; White et al. 1984 \& 1986; Molz et al. 1986; Nielson et al. 1973; Van de Pol et al. 1977; Biggar and Nielson 1976; Sharma et al. 1980; Smith et al. 1985). These studies suggest that the appropriate transfer function is a log normal distribution. This distribution has a peak (near the $\ln$ mean transit time) and is skewed to the right. As show below, the distribution as a function of time is entirely defined by the $\mu$ and $\sigma$.

$$
F_{t}=\frac{1}{\sigma t \sqrt{2 \pi}} \exp \left(-0.5\left(\frac{\ln (t)-\mu}{\sigma}\right)^{2}\right)
$$

Figure 5 shows an example transfer function generated by the model. Both of the curves shown (with and without decay) are calculated for each run. This provides a quality assurance check and documents the amount of contaminant lost by radioactive decay during transit. As described above, the flux of contaminant to the stream in any year is simply the sum of the estimated contributions from all of the previous years disposals to the facility:

$$
\text { stream flux (year } \left.j)=\sum_{i=1957}^{j} \text { basin flux (year } i\right) x F_{j-i}
$$

The historical tritium input measurements to the $\mathrm{F}$ and $\mathrm{H}$ Area Basins and the historical tritium flux measurements to Fourmile Branch downgradient of these basins are shown in Table 1. The values in this table do not include monitoring stations FM3A-FM3 since this reach of the $F$ Area drainage tributary is receiving tritium primarily from the SWDF. The values in Table 1 serve as the calibration targets for estimating $\mu$ and $\sigma$ for each area. Based on minimizing the sum of the squares of the differences between model predictions and the measurements, the following transfer function parameters were selected ( $t$ in years):

$$
\begin{aligned}
& \text { H Area: } \mu=2.0 \text { and } \sigma=2.0 \\
& \text { F Area: } \mu=2.6 \text { and } \sigma=0.8
\end{aligned}
$$

Figures 6 and 7 show the calibration results for $\mathrm{H}$ Area and F Area, respectively. The $\mathrm{H}$ Area calibration match is good. The F-Area model is generally good; note, however, the F Area model overpredicts the fluxes through the early 1980 s and then underpredicts fluxes 
during later time. Several operational changes were made to the F-Area Basins during the 1980s (higher banks were added, algae control was initiated, flow rates varied, etc.).

Additionally, some of the trees near the seep line downgradient of the basin were lost during this peirod, modifying the flow dynamics somewhat. Related large-scale engineering activities were performed nearby during this period, tree harvests and the new F-Area engineered drainage were installed, potentially modifying plume behavior from all facilities in the area. These factors have been identified for more careful evaluation using numerical modeling. Overall, the performance of both the H-Area and F-Area transfer function models appears adequate for initial projections of tritium flux and estimation of corrective action system impacts.

To evaluate pump-treat-reinjection performance, the following modifications to the transfer function approach were made. The approximate percent reduction in flux from the plume was calculated using measured water balances in the vicinity, results from the well field layout analytical element models (QUICKFLOW), and available numerical modeling. Following assumed implementation of the system, the calculated percentage was removed from the downgradient flux each year and placed upgradient, near the basins, as a new source. At this point, the new source was allowed to behave according to the original transfer function. This assumes that any contaminant forced outside of the zone of capture will behave approximately to the unmodified system, and that (at low flow rates) the original function is sufficient to describe the flow within the active zone between the injection and extraction systems.

Figures 8 and 9 show the approximate behavior of the tritium flux as a function of near-term remediation system implementation for $\mathrm{H}$ Area and $\mathrm{F}$ Area, respectively. Each figure shows the no action case and a $100 \mathrm{gpm}$ pump-treat-reinjection system assumed to be implemented in 1997. The no action case shows the reduction in tritium flux versus time due to natural flushing and radioactive decay following basin closure. The $100 \mathrm{gpm}$ pump-treat-reinjection case assumes an approximate steady-state tritium flux interception of $65 \%$ (H Area) and $45 \%$ (F Area). The remediation plots illustrate the expected remediation system performance. The estimated total (past and projected) curies of tritium released to Fourmile Branch waters for the no action (baseline) cases are $212000 \mathrm{Ci}$ and $135000 \mathrm{Ci}$ for $\mathrm{H}$ and $\mathrm{F}$ Area, respectively. Of this total, the model projects future fluxes to Fourmile Branch of $16769 \mathrm{Ci}$ (H Area) and $22352 \mathrm{Ci}$ (F Area) if no remediation is performed. These totals decrease for the various scenarios as follows:

$\mathrm{H}$ Area (changes in total tritium release):

no action (baseline): $0 \mathrm{Ci}$

$100 \mathrm{gpm}$ pump-treat-reinjection system: $-7500 \mathrm{Ci}$

F Area (changes in total tritium release):

no action (baseline): $0 \mathrm{Ci}$

$100 \mathrm{gpm}$ pump-treat-reinjection system: $-5500 \mathrm{Ci}$

A larger variety of remediation system scenarios and more precise estimates of flux reduction are principal objectives of the current numerical modeling effort that will support final corrective action decisions. 


\section{Solid Waste Disposal Facilities (SWDF)}

Centrally located solid waste storage/disposal facilities have been used for all of the radioactive solid waste produced at SRS and occasional shipments from offsite. There are three facilities covering a total of approximately 200 acres that have received this waste:

- an original facility of approximately 80 total acres that received waste between 1953 and 1972 (Facility 643E)

- a contiguous area of approximately 120 total acres containing two facilities (643-7E and 643-28E) that received waste after the original area was filled.

The SW/DF were operated for the managed storage or disposal of solid radioactive wastes in underground trenches or on covered pads at the surface. Examples of materials received by the SWDF are as follows (Fenimore and Hooker 1977):

- Contaminated Equipment - Obsolete or failed tanks, pipes, spent deionizers, and other process equipment.

- Reactor and Fuel Hardware - Fuel components and housings not containing fuel or products.

- Spent Lithium Aluminum Targets - The waste target alloy after tritium was extracted by melting.

- Contaminated Nonrecoverable Mercury - Residual from mercury recovery units, packaged in sealed containers.

- Oil from Gas Displacement Pumps - Prior to burial, oil was placed in drums containing sorbent material.

- Laboratory and Operating Waste - clothes, sheeting, decontamination residue, and other materials.

- Special Shipments from Offsite - for example, tritiated waste from Mound Laboratory.

From this list, the primary forms of tritium-containing waste in the SWDF are the waste crucibles from the tritium extraction process, other process vessels, and job control waste that contained tritium. The waste crucibles are steel cylinders containing lithium/aluminum alloy and residual tritium. Beginning in 1987, the open ends of the crucible were sealed with an epoxy-type plug to minimize the release of tritium.

The various wastes were segregated into different trenches based on radioactive content and material types. All of the trenches were covered with soil to isolate the waste. Over the years, operations shifted from open trenches to "engineered low-level trenches," improving somewhat the isolation of the waste from the environment. Additionally, 643-28E was 
capped with low permeability clay to reduce infiltration of water. Thus, the highest concentrations and fluxes of tritium and other relatively mobile radionuclides from the waste are beneath the original burial facility (643E). Records on the locations of the trenches and a description of the type and radiation levels of the waste were maintained for the facility. These records were computerized in 1976 and they form the basis for estimating the quantity of various nuclides in the facility. A new facility has been added to the SWDF for future disposal. This facility employs vault storage to provide an even higher level of protection from the waste, effectively decoupling the waste from the soil and groundwater

As described above, contaminant fluxes from the original burial area (643E) represent the most significant releases from the SWDF. This is due to a combination of burial practices, wastes received by the facility, and proximity to a receiving stream. Water beneath $643 \mathrm{E}$ flows toward the south and west, cropping out in a natural tributary of Fourmile Branch, the F-Area drainage tributary. Thus, water flows beneath the facility, exiting in the southwest corner (Albenesius and Fenimore 1979). As with the seepage ba.:as, the flow follows a curved path -- downward through the water table into the semicor.ined zone beneath the site and curving upward as the plume approaches the F Area drainage tributary. Initially, data from the $F$ Area drainage tributary did not clearly differentiate between fluxes from the SWDF and the H Area Seepage Basins (Albenesius and Fenimore 1979). Subsequent sampling and groundwater plume maps (see Figure 2), however, indicate that the primary source of contaminant to this stream reach is the SWDF.

Early (1957) burial of lithium/aluminum melts in the southwest corner of the facility, and subsequent burials throughout $643 \mathrm{E}$ provide a relatively long term and stable source of tritium to the flowing groundwater. In fact, as shown in Table 2, stations monitoring the F Area drainage tributary (FM3A-FM3) have shown relatively stable fluxes over the entire period of measurement (1981 through the present). During this period, these fluxes ranged from 2035 to $7295 \mathrm{Ci} / \mathrm{yr}$ with an average of approximately $4500 \mathrm{Ci} / \mathrm{yr}$. As early as 1979, a flux of approximately $4000 \mathrm{Ci}$ was measured in this stream (Albenesius and Fenimore 1979). Estimated transit times (Stone and Christensen 1983) from 643E to the tributary range from as low as 22 years (southwest corner) to as high as 100 years (southeast corner). We anticipate, with no corrective action, that tritium fluxes will be elevated during this period. In the near term, tritium fluxes at approximately current levels are expected. Through the years, these fluxes will fluctuate depending on the contributions of various parts of the facility to the flowing groundwater. Over a longer period, tritium fluxes would decline as a result of radioactive decay and depletion of the original source. As discussed below, any corrective actions for the facility would reduce tritium fluxes.

Based on the operational history of the $643 \mathrm{E}$, the measured fluxes over the last 10 years, and the geology and hydrology of the site, we can develop a projection of SWDF tritium release to Fourmile Branch. We postulate that SWDF tritium fluxes to Fourmile Branch reached an approximately steady level in 1977, representing the arrival of water from the southwest corner of the facility. Further, we postulate that, with no corrective action, the fluxes will remain at these levels (about $4500 \mathrm{Ci} / \mathrm{yr}$ ) until at least year 2010. Extrapolation beyond this period requires additional data. We are planning specific characterization activities (see below) that will allow substantial improvement in this estimate. While corrective actions are 
expected to reduce releases, we can not currently estimate their impact because specific activities are not currently identified and permitted.

Several specific characterization activities related to tritium fluxes from $643 \mathrm{E}$ to Fourmile Branch are planred. These include depth discrete (3D) sampling of the tritium plume exiting the southwest corner of the facility to determine its characteristics. Second, improved source characterization is planned. Using the burial records, surface geophysics, soil gas surveys and other tools, we will improve the identification of the locations of contaminant sources, including the major tritium sources, in the facility. We plan additional sampling and characterization in downgradient areas where the tritium is cropping out. Finally, we will incorporate new geology and hydrology data into the projections. These data include improved interpretation of the lithology of the site, better definition of vertical gradients, and new pump test information. The additional characterization information will allow a significantly improved projection of tritium flux.

Similar to the F and H Area Seepage Basins, SRS and the South Carolina Department of Health and Environmental Control (DHEC) are currently developing groundwater corrective action plans for the SWDF. Portions of the SWDF is are also regulated under the Comprehensive Environmental Response, Compensation, and Liability Act (CERCLA); CERCLA characterization and assessment are also underway. Reduction of tritium flux is one of the factors considered in the development of the RCRA/CERCLA groundwater corrective action. Low permeability caps, wasteform stabilization, groundwater barriers, groundwater pump-treat-reinjection, and other technologies are all under consideration as components of the SWDF remediation.

\section{Projected Tritium Releases from F \& H Area Seepage Basins and the SWDF to Fourmile Branch}

In this section, we combine the historical and projected tritium releases from the various facilities to Fourmile Branch (Figure 10). Actual (measured) releases are plotted through 1992, and projections are plotted thereafter. The projections are most reliable the next few years. The graph includes the impacts of the permitted groundwater corrective actions at the $\mathrm{F}$ and $\mathrm{H}$ Area Seepage Basins; note the relatively rapid decline in releases in 1997 . No credit was taken for corrective action at the SWDF since the nature and impact of the remediation is currently not defined. Thus, we anticipate that the estimates are conservative (high) beyond approximately year 2000 . 


\section{References}

Albenesius, E. L. and J. W. Fenimore, 1979. Tritium Migration from the Burial Ground to Four Mile Creek - Reappraisal of Flow Paths and Travel Times, DPST-79-265, E. I. du Pont de Nemours and Co., Savannah River Laboratory, Aiken SC 29808.

Biggar, J. W. and D. R. Nielson, 1987. Spatial variability of the leaching characteristics of a field soil, Water Resources Research, 23, 1876-1886.

Corbo, P., M. V. Kantello, and C. B. Fliermans, 1985. Basin Characterization Summary: Analytical Results, Database Management, and Quality Assurance Results for Analysis of Soil Cores from the F-and H-Area Seepage Basins, DPST-85-921, E. I. du Pont de Nemours and Co., Savannah River Laboratory, Aiken SC 29808.

Christensen, E. J., and D. E. Gordon, 1983. Technical Summary of Groundwater Quality Protection Program at the Savannah River Plant, DPST-83-829, E. I. du Pont de Nemours and Co., Savannah River Laboratory, Aiken SC 29808.

Cummins, C. L., D. K. Martin and J. L Todd, 1991. Savannah River Site Environmental Report: 1990. WSRC-IM-91-28, Westinghouse Savannah River Company, Aiken SC 29808 .

Dixon, K. L. and V. A. Rogers, 1992. Results of the First Quarter Tritium Survey of the Fand H-Area Seeplines: May 1992. WSRC-TR-92-304, Westinghouse Savannah River Company, Aiken SC 29808.

Fenimore, J. W., and J. H. Horton Jr., 1968. Influence of High Level Waste Salts on Movement of Strontium and Cesium in Savannah River Plant Soil, DP-1124, E. I. du Pont de Nemours and Co., Savannah River Laboratory, Aiken SC 29808.

Fenimore, J. W., and J. H. Horton Jr., 1972. Operating History and Environmental Effects of Seepage Basins in Chemical Separations Areas of the Savannah River Plant, DPST72-548, E. I. du Pont de Nemours and Co., Savannah River Laboratory, Aiken SC 29808 .

Fenimore, J. W. and R. L. Hooker, 1977. The Assessment of Solid Low-Level Waste Management at the Savannah River Plant, DPST-77-300, E. I. du Pont de Nemours and Co., Savannah River Laboratory, Aiken SC 29808

Haselow, J. S., M. Harris, B. B. Looney, N. V. Halverson, and J. B. Gladden, 1990. Analysis of Soil and Water at the Four Mile Creek Seepline near the F\&H Areas of SRS, WSRC-RP-90-0591, Westinghouse Savannah River Company, Savannah River Laboratory, Aiken SC 29808. 
Hubbard, 1986. An i'ndate on the SRP Burial Ground Area Water Balance and Hydrology, DPST-85-958. E. I. du Pont de Nemours and Co., Savannah River Laboratory, Aiken SC 29808

Jury, W. A., 1982. Simulation of solute transport using a transfer function model, Water Resources Research, 18, 363-368.

Jury, W. A., L. H. Stolzy and P. Shouse, 1982. A field test of the transfer function model for predicting solute transport, Water Resources Research, 18, 369-375.

Jury, W. A., G. Sposito, snd R. E. White, 1987. A transfer function model of solute transport through soil, 1. fundamental concepts, Water Resources Research, 22, 243-247.

Killian, T. H., N. L. Kolb, P. Corbo, and I. W. Marine, 1987a. Environmental Information Document: F-Area Seepage Basins, DPST-85-704, E. I. du Pont de Nemours and Co., Savannah River Laboratory, Aiken SC 29808.

Killian, T. H., N. L. Kolb, P. Corbo, and I. W. Marine, 1987b. Environmental Information Document: H-Area Seepage Basins, DPST-85-706, E. I. du Pont de Nemours and Co., Savannah River Laboratory, Aiken SC 29808.

Looney, B. B., J. E. Cantrell, and J. R. Cook, 1988. Sampling and Analysis of Surface Water in the Vicinity of the F-and H-Area Seepage Basins, DPST-88-229, E. I. du Pont de Nemours and Co., Savannah River Laboratory, Aiken SC 29808.

Molz, F. J., O. Guven, J. G. Malville, R. D. Crocker, and K. T. Matteson, 1986, Performance, analysis and simulation of a two well tracer test at the Mobile Site, Water Resources Research, 22, 1031-1037.

Nielson, D. R., J. W. Bigger, and K. T. Erh, 1973. Spatial variability of field measured soil properties, Hilgardia, 42, 215-260.

Sharma, M. L., G. A. Gander, and C. G. Hunt, 1980. Spatial variability of infiltration in a watershed, Jour. Hydrology, 45, 101-122.

Smith, M. S., G. W. Thomas, R. E. White, and D. Ritonga, 1985. Transport of Escherichia coli through intact and disturbed columns of soil, Jour. Environmenatal Quality, 14, 87-91.

Stone, J. A. and E. J. Christensen, 1983. Technical Summary of Groundivater Protection at Savannah Riyer Plant: Volume II, Radioactive Wastes, DPST-83-829 vol 2, E. 1. du Pont de Nemours and Co., Savannah River Laboratory, Aiken SC 29808.

Van de Pol, R. M., P. J. Wierenga, and D. R. Nielson, 1977. Solute movement in a field soil, Soil Science Soc. of America Jour., 41, 10-13. 
White, R. E., G. W. Thomas, and M. S. Smith, 1984. Modeling water flow through undisturbed cores using a transfer function model derived from tritium and chloride transport, Jour. Soil Science, 35, 159-16r.

White, R. E., J. S. Dyson, R. A. Haigh, W. A. Jury, and G. Sposito, 1986. A transfer function model of solute transport through soil, 2: illustrative applications, Water Resources Research, 21, 447-457. 
Table 1. Historical Tritium Flux Data for the $\mathrm{F}$ and $\mathrm{H}$ Area Seepage Basins

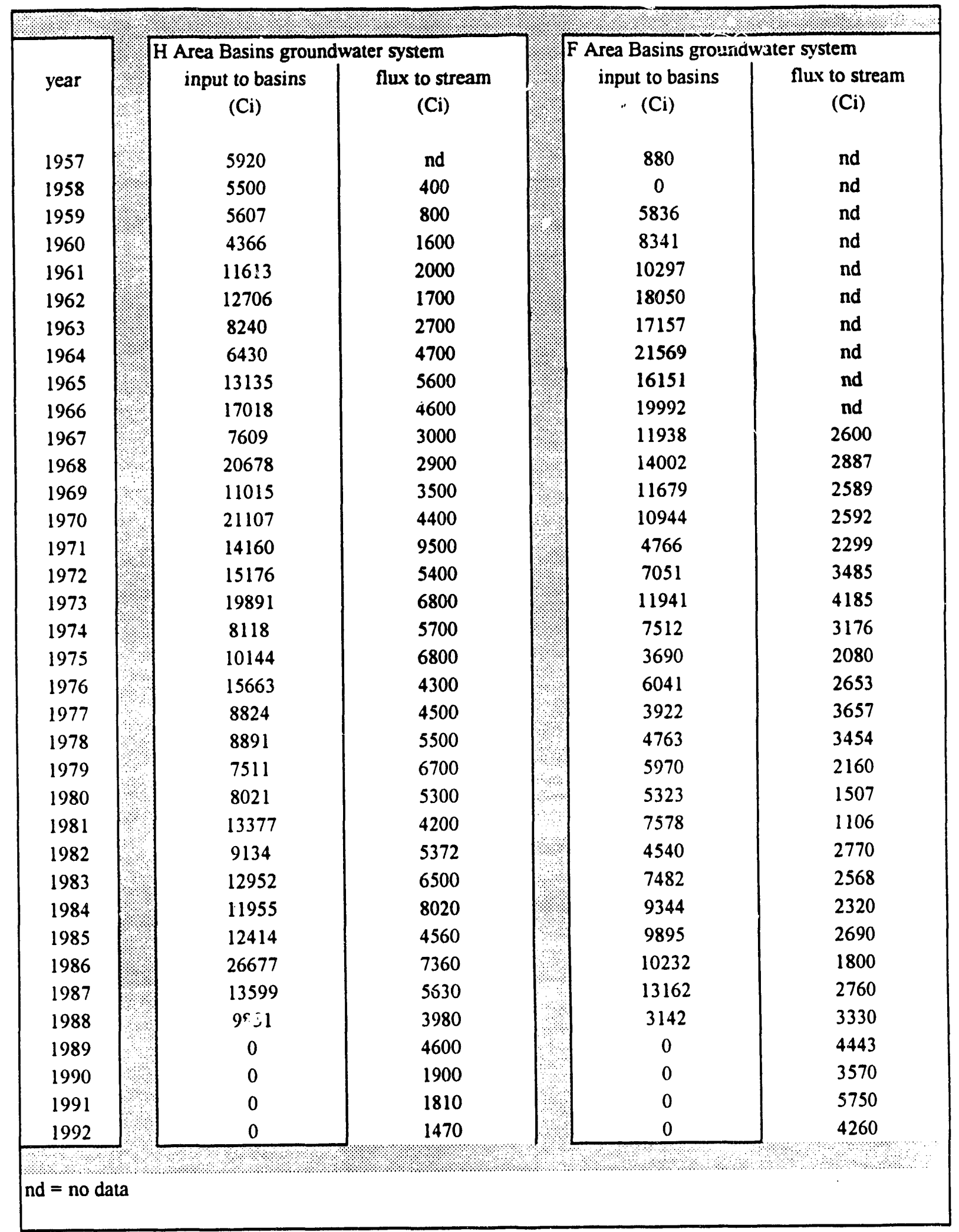


Table 2. Approximate Flux from 643E to Tributary of Fourmile Branch (Station FM3A-FM3)

\begin{tabular}{rrr|r} 
Year & $\begin{array}{c}\text { Tritium Flux } \\
(\mathrm{Ci} / \mathrm{yr})\end{array}$ & notes \\
& & & \\
1979 & 4000 & 1 & \\
1980 & nd & 2 & \\
1981 & 2035 & 3 & \\
1982 & 3291 & 3 & \\
1983 & 4018 & 3 & \\
1984 & 4480 & 3 & \\
1985 & 7295 & 3 & \\
1986 & 5210 & 3 & \\
1987 & 6150 & 3 & \\
1988 & 3670 & 3 & \\
1989 & 3600 & 3 & \\
1990 & 4280 & 3 & \\
1991 & 6420 & 3 & \\
1992 & 4090 & &
\end{tabular}

1 = estimated from Albenesius and Fenimore, 1979

2 = no data

3 = estimated from Annual Environmental Reports 


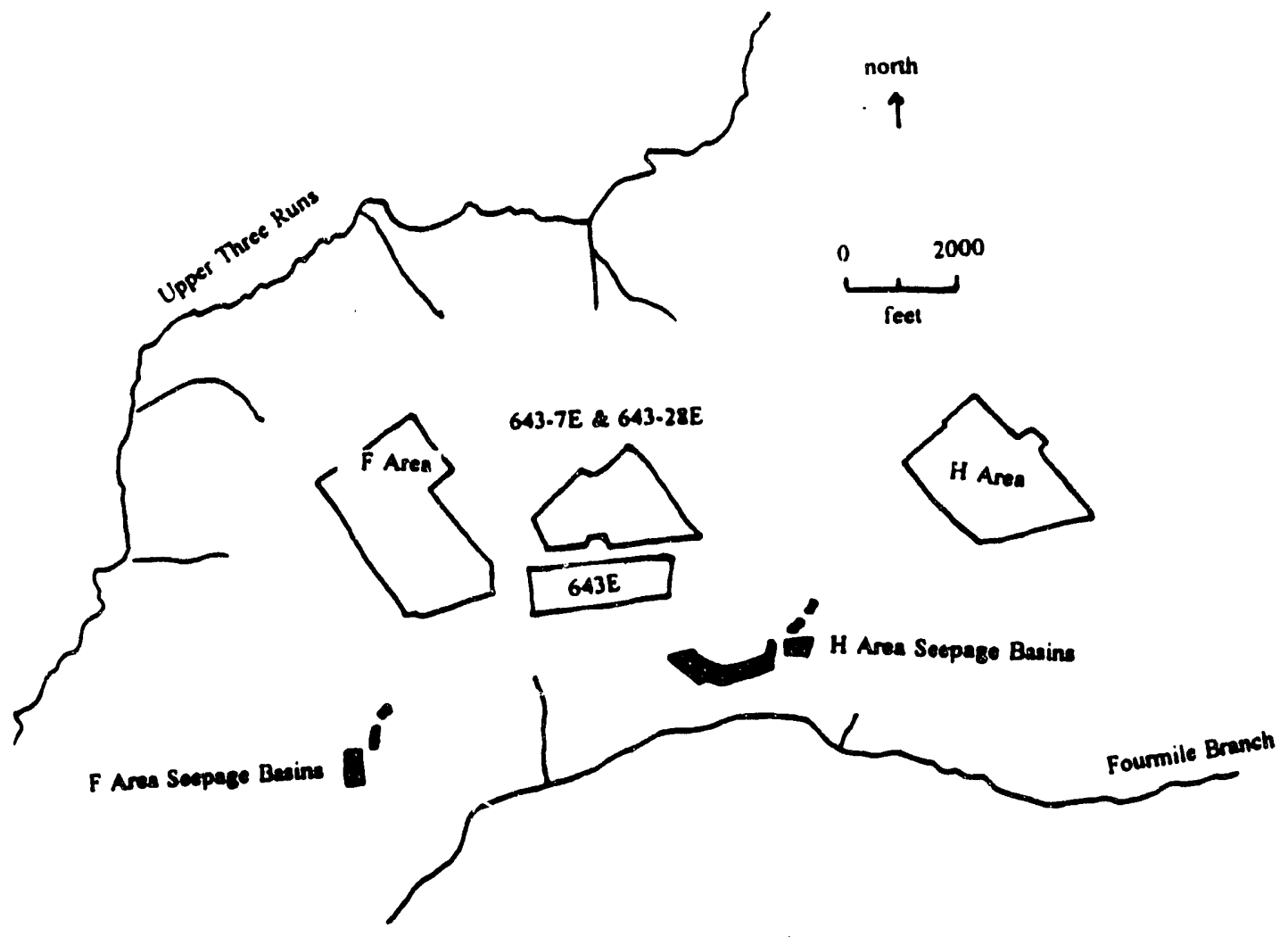

Figure 1. Location of the F and H Area Seepage Basins and the SWDF at SRS 


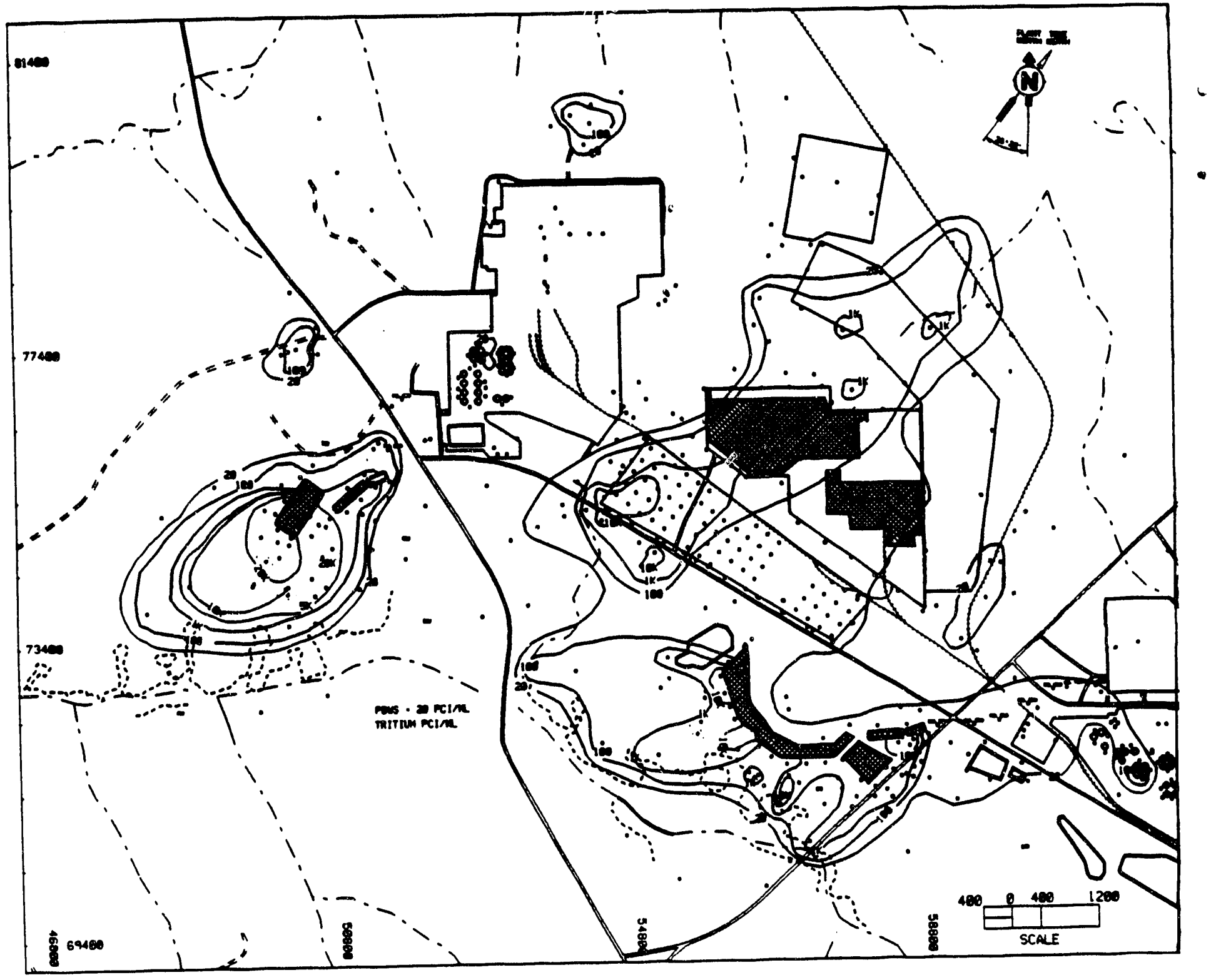

Figure 2. Recent map showing the tritium plume in the vicinity of the $F$ and $H$ Area Seepage Basins and the SWDF 


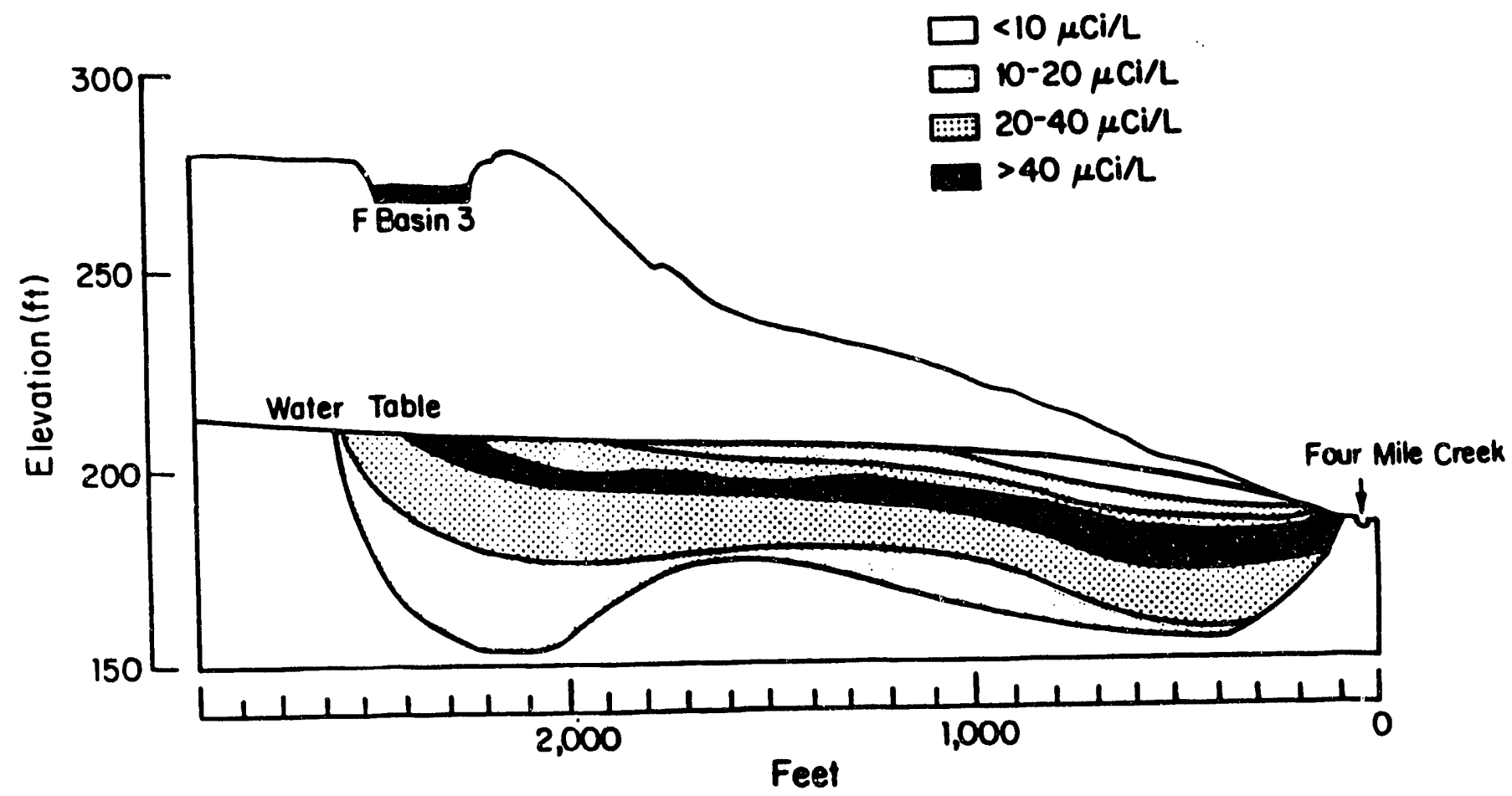

Figure 3. Example plume trajectory: Vertical distribution of tritium in groundwater downgradient of the F Area Seepage Basins 


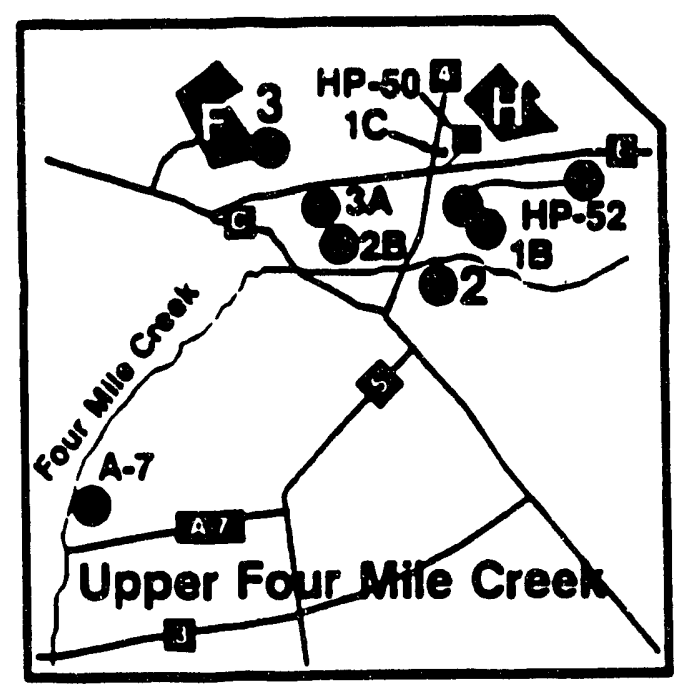

Fluxes in the various stream reaches are related to the facilities as follows:

F Area Seepage Basins to Fourmile Branch $=$ FMA7 - (FM3A + FM2B)

H Area Seepage Basins to Fourmile Branch $=$ FM2B - FM1C

SWDF (principal source) and H Area Seepage Basin 4 to Fourmile Branch $=$ FM3 A - FM3

Figure 4. Surface water monitoring in the vicinity of the $F$ and $H$ Area Seepage Basins and the SWDF 
Transfer Function Example - relative flux at seep line from one years input to basins

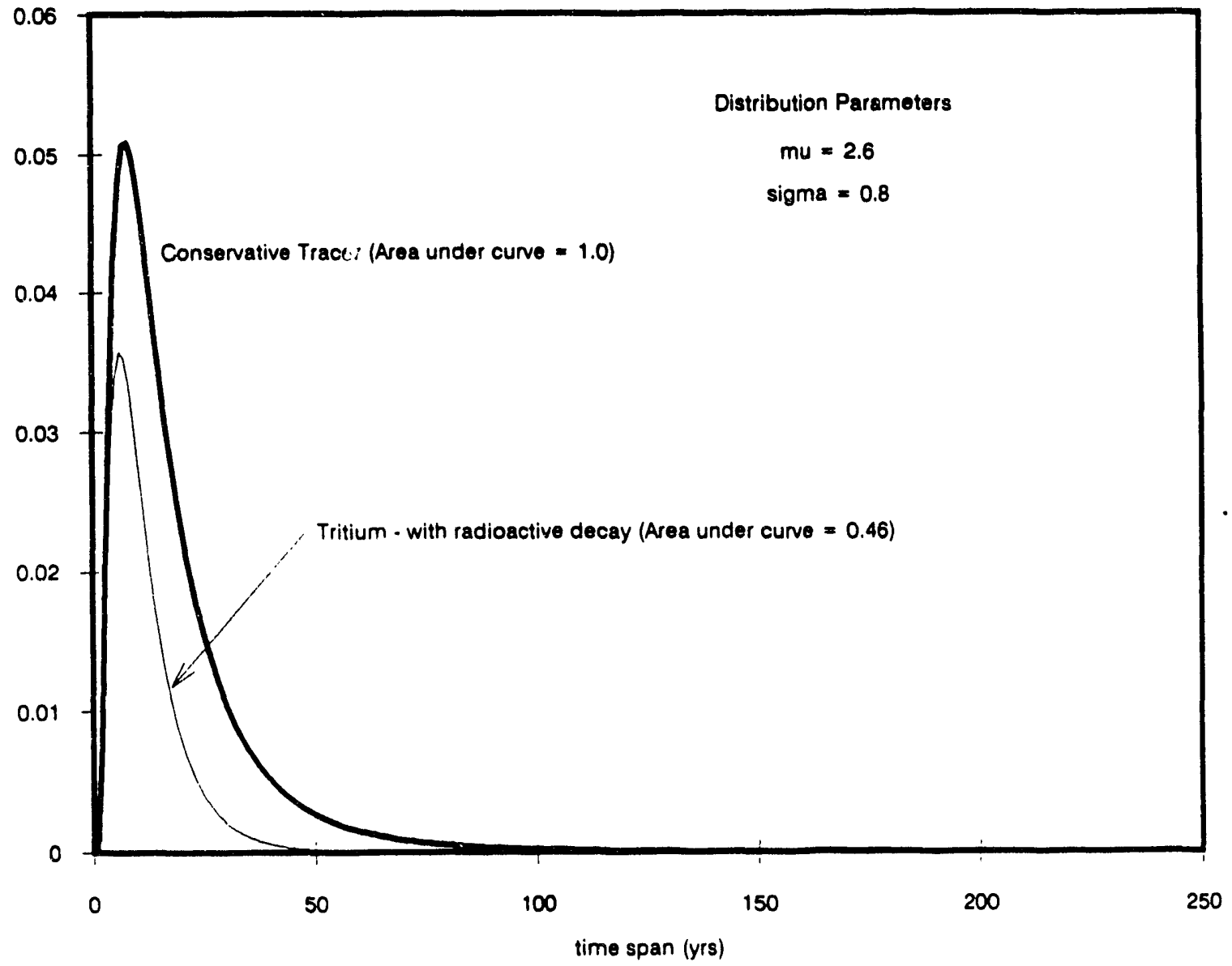

Figure 5. Example of transfer function $\left(F_{1}\right)$ 


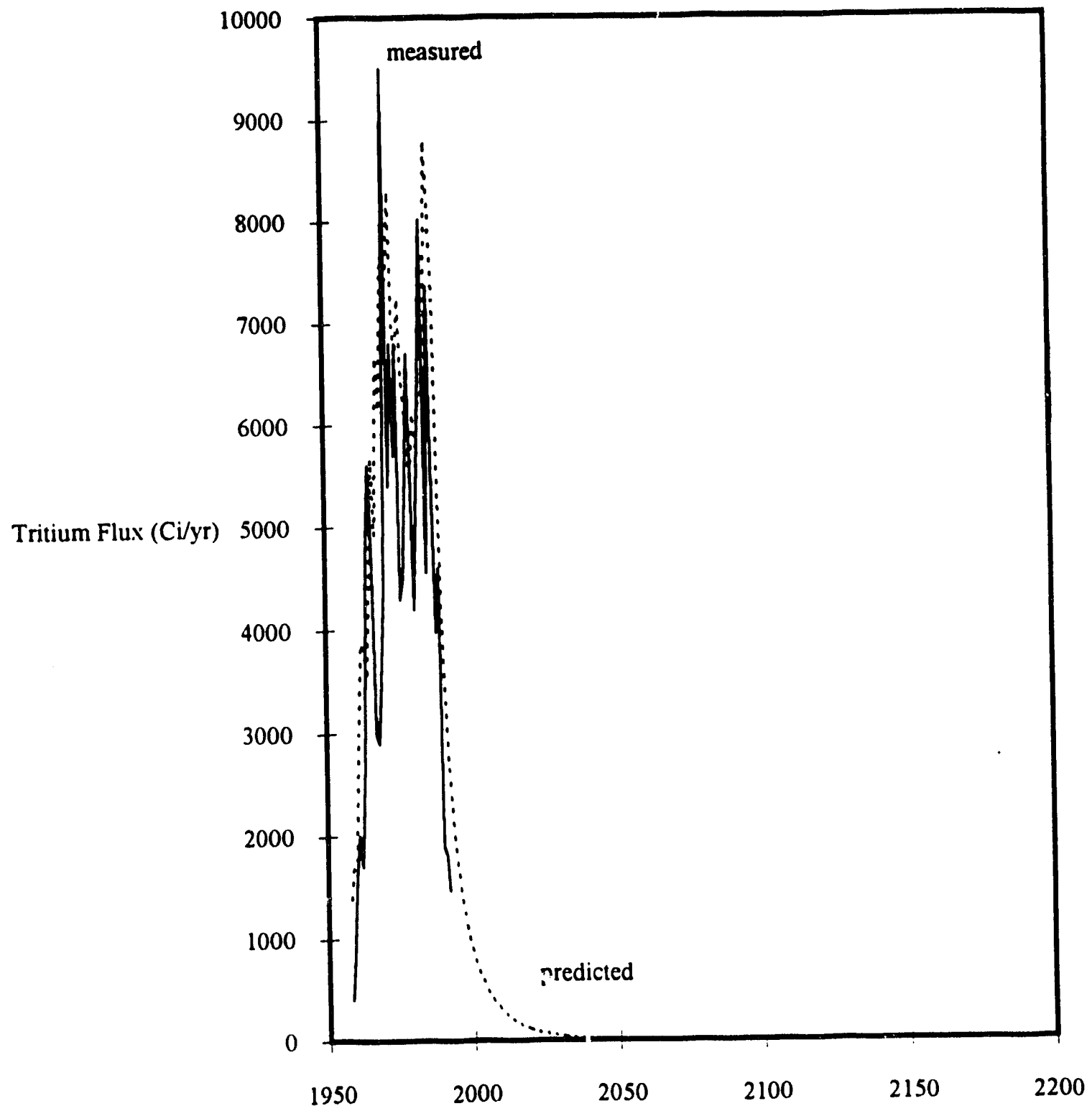

Figure 6. Results of $\mathrm{H}$ Area Seepage Basins transfer function calibration 


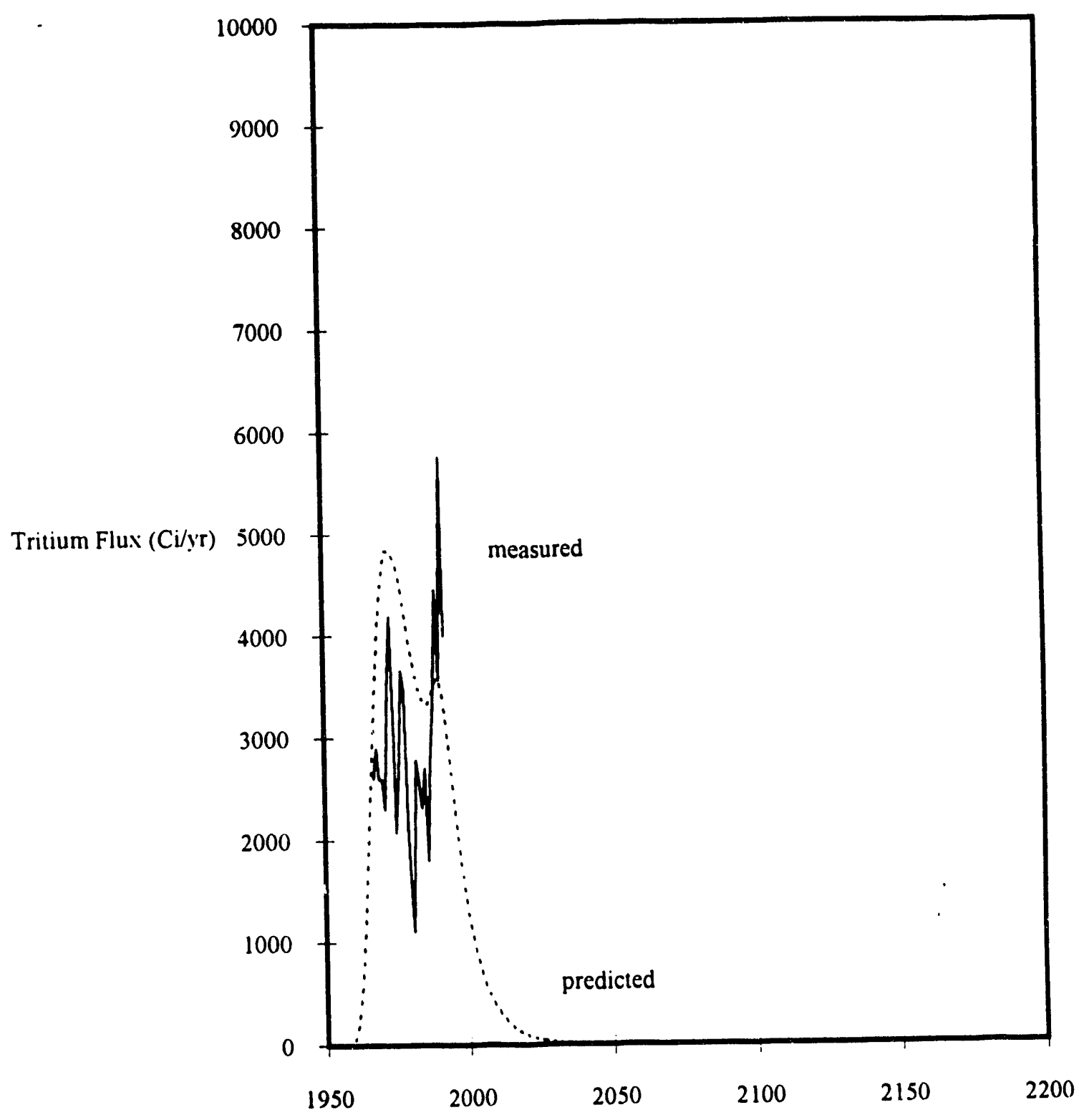

Figure 7. Results of the F Area Seepage Basins transfer function calibration 


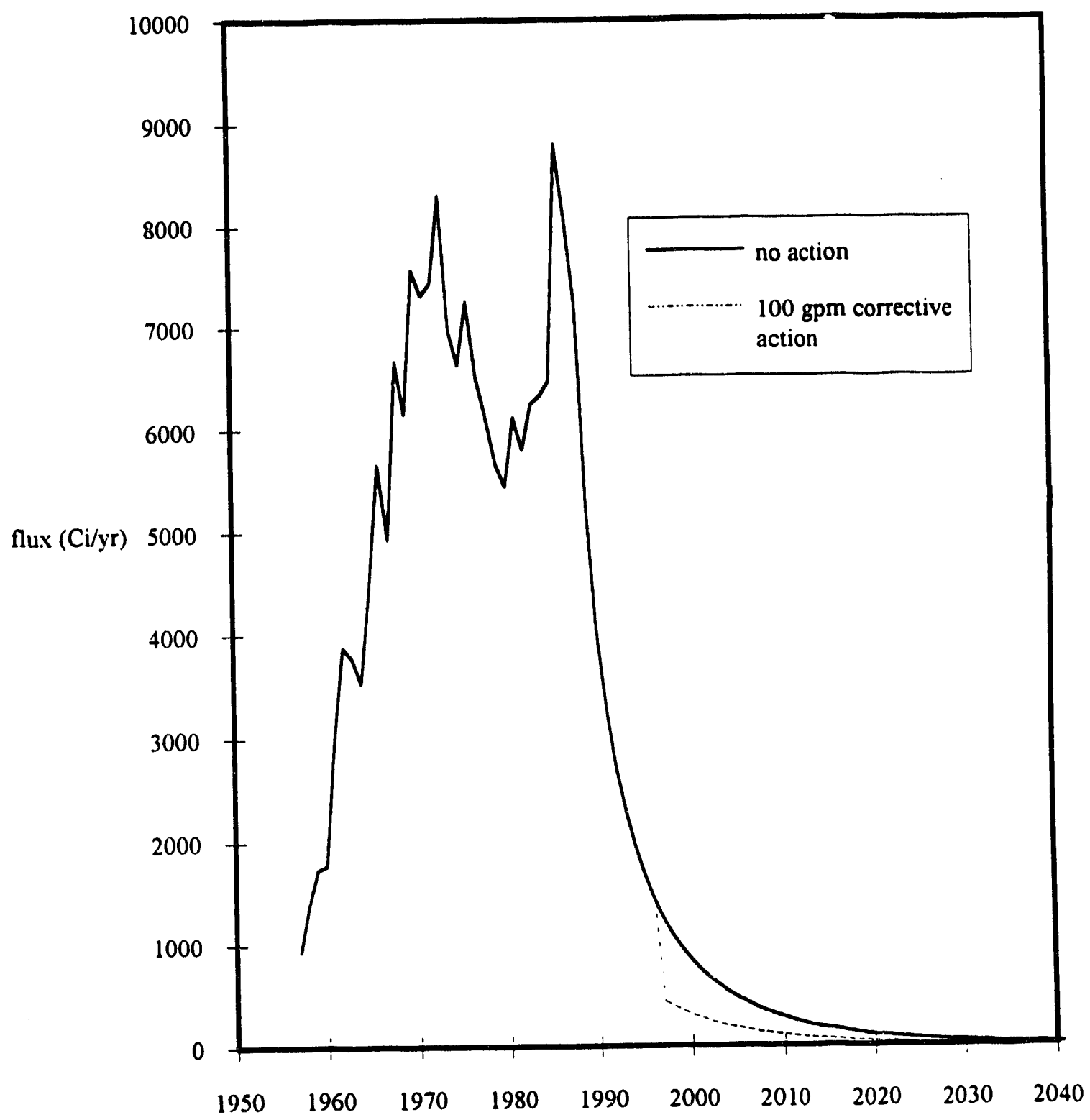

Figure 8. Past and projected tritium fluxes to Fourmile Branch from the H Area Seepage Basins for the no action case and the permitted groundwater corrective action. 


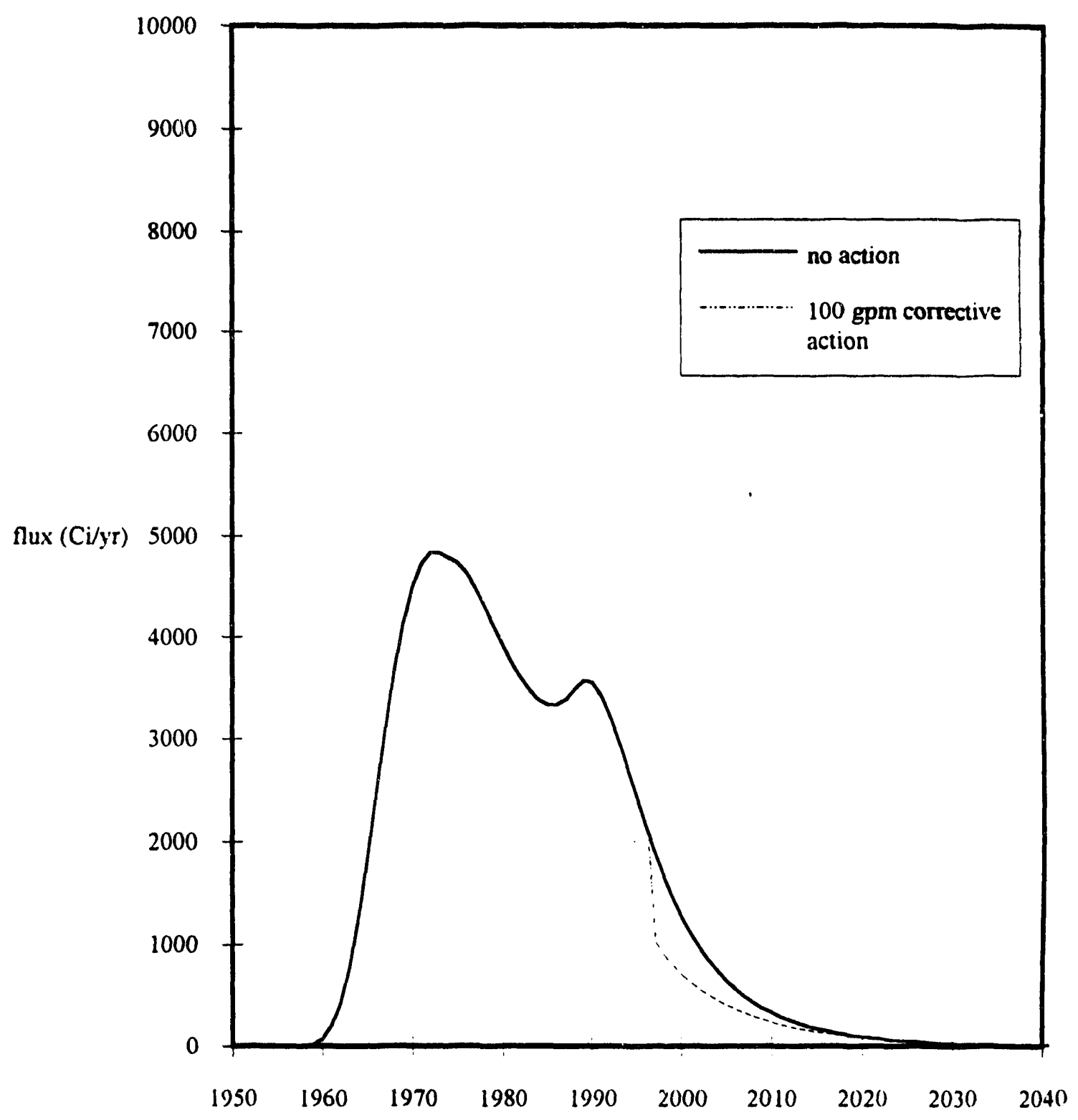

Figure 9. Past and projected tritium fluxes to Fourmile Branch from the F Area Seepage Basins for the no action case and the permitted groundwater corrective action. 
Near Term Tritium flux to Fourmile Branch from the F\&H Basins and the SW conter of $643 E$

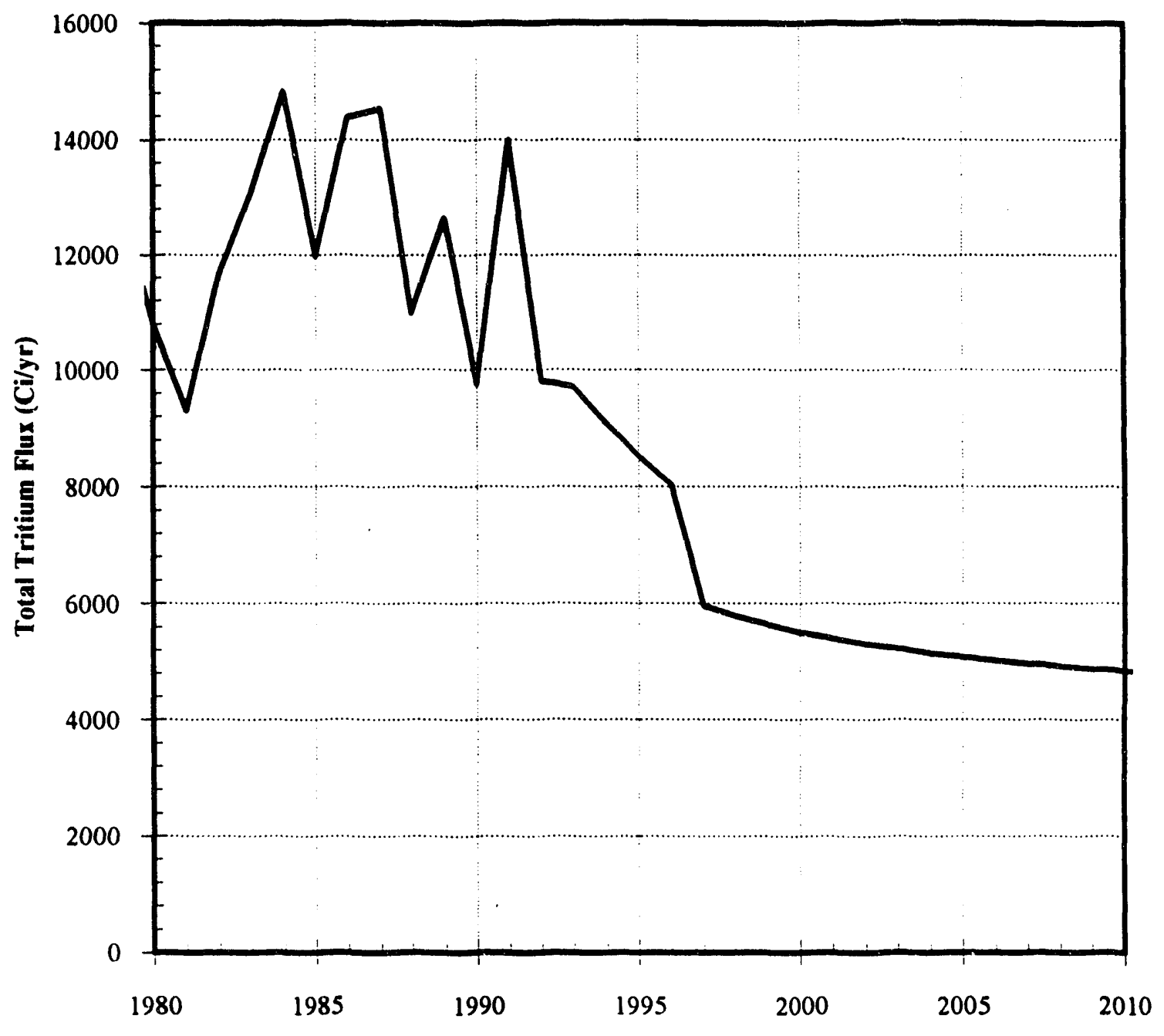

Figure 10. Sum of the past and projected tritium fluxes to Fourmile Branch from the $F$ and $\mathrm{H}$ Area Seepage basins and the SWDF. 

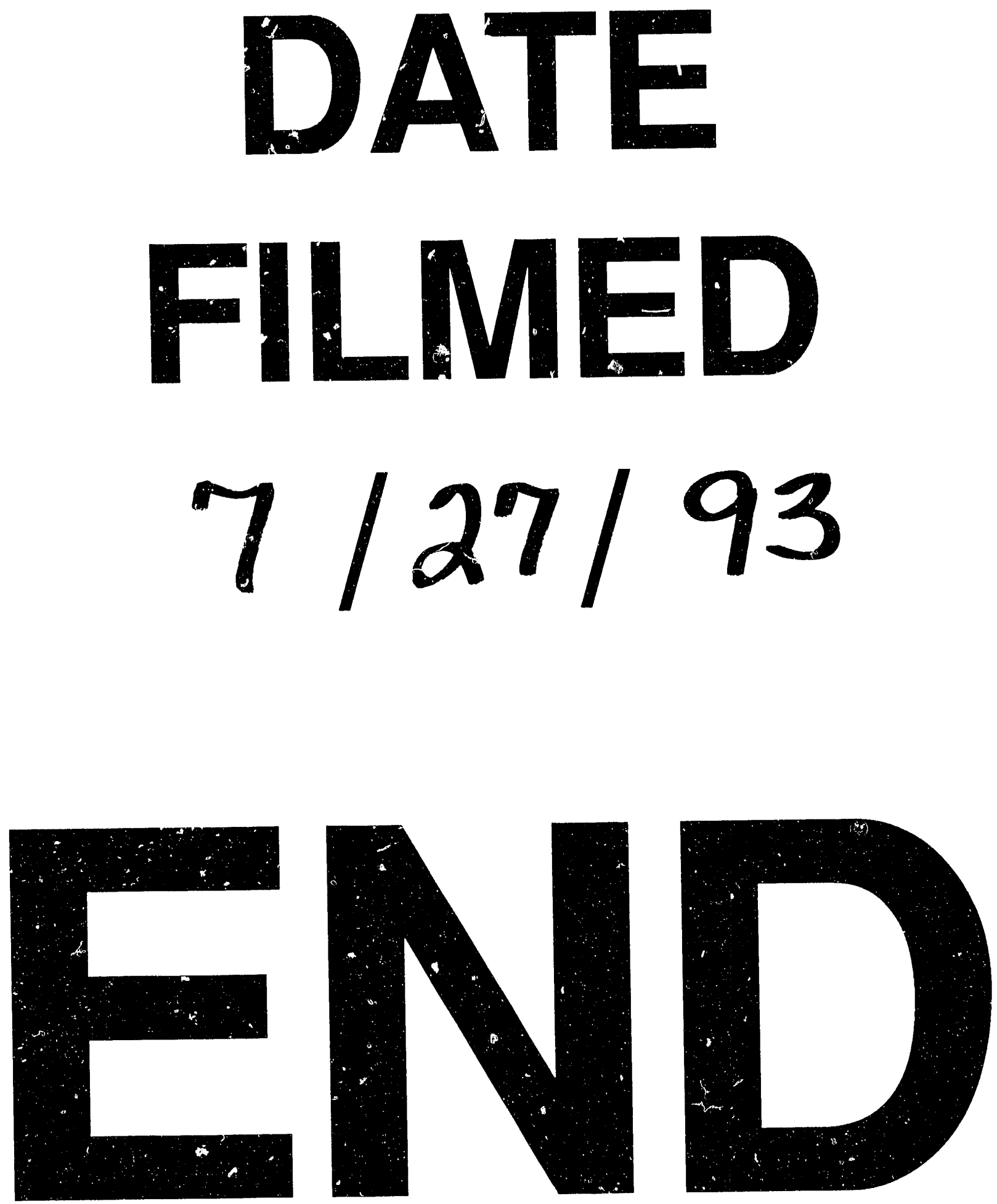
